\title{
Regulation of parathyroid hormone-related protein gene expression by epidermal growth factor-family ligands in primary human keratinocytes
}

\author{
Yong-Mee Cho ${ }^{1}$, Davina A Lewis ${ }^{2}$, Peter F Koltz ${ }^{1}$, \\ Virgile Richard ${ }^{3}$, Todd A Gocken ${ }^{1}$, Thomas J Rosol ${ }^{3}$, \\ Raymond L Konger $^{2,5}$, Dan F Spandau ${ }^{2,4}$ and John Foley ${ }^{1,2}$ \\ ${ }^{1}$ Medical Sciences, Indiana University School of Medicine, Bloomington, Indiana 47405, USA \\ ${ }^{2}$ Department of Dermatology, Indiana University School of Medicine, Indianapolis, Indiana 46202, USA \\ ${ }^{3}$ The Ohio State University Department of Veterinary Biosciences, Columbus, Ohio 43210, USA \\ ${ }^{4}$ Department of Biochemistry and Molecular Biology, Indianapolis School of Medicine, Indianapolis, Indiana 46202, USA \\ ${ }^{5}$ Department of Pathology and Laboratory Medicine, Indianapolis School of Medicine, Indianapolis, Indiana 46202, USA \\ (Requests for offprints should be addressed to J Foley, Medical Sciences, Indiana University, Jordan Hall 105, Bloomington, Indiana 47405-4401, USA; \\ Email: jgfoley@indiana.edu)
}

\begin{abstract}
Cultured primary human keratinocytes were the first non-cancer-derived cell type reported to produce the humoral hypercalcemia factor, parathyroid hormonerelated protein (PTHrP). Emerging evidence suggests that only a subset of keratinocytes produce high levels of $\mathrm{PTHrP}$ in vivo. We found that the PTHrP mRNA content of intact human skin was minimal, whereas transcripts were easily detectable in primary keratinocytes derived from those skin samples. We hypothesized that conditions associated with growth in culture activated PTHrP gene expression in primary keratinocytes. In culture, keratinocytes produce a number of epidermal growth factor (EGF)-like ligands (transforming growth factor-alpha, heparin binding-EGF and amphiregulin) and their receptor, ErbB1. Treatment of keratinocytes with a specific erbB1 inhibitor (PD153035) reduced PTHrP mRNA levels by $>80 \%$ in rapidly growing keratinocytes. Treat-
\end{abstract}

ment of keratinocytes with reagents that neutralize amphiregulin reduced PTHrP mRNA levels by $\sim 60 \%$. Blockade of erbB1 signaling reduces transcription from the endogenous PTHrP P3-TATA promoter. The Ets transcription factor-binding site, 40 bases upstream of the P3 promoter, is required for baseline expression of PTHrP reporter gene constructs in keratinocytes; in addition, cotransfection of Ets-1 and Ets-2 expression vectors activate the reporter gene constructs. Finally, disruption of both ras and raf signaling reduce reporter gene expression by $80 \%$, suggesting that ErbB1 signaling is mediated by the classic ras/MAP kinase pathway. These findings suggest that acquisition of EGF-like ligand expression has the potential to substantially activate PTHrP gene expression in the epidermis.

Journal of Endocrinology (2004) 181, 179-190

\section{Introduction}

Parathyroid hormone-related protein (PTHrP) was initially identified in association with the paraneoplastic syndrome, humoral hypercalcemia of malignancy. This syndrome is produced when tumor-derived N-terminal PTHrP enters the circulation and stimulates the parathyroid hormone (PTH)/PTHrP receptor (PTHR) in bone and kidney, resulting in hypercalcemia (Broadus et al. 1988). Paracrine activation of the PTHR by PTHrP regulates the development of several organ systems including the long bone, tooth, mammary gland and epidermal appendages (Karaplis et al. 1994, Philbrick et al. 1998, Wysolmerski et al. 1998, Cho et al. 2003).
The human PTHrP gene is a complex transcriptional unit composed of nine exons spanning more than $15 \mathrm{~kb}$ of genomic DNA (Gillespie \& Martin 1994). Transcription of the gene may be initiated at any one of three promoters: P1, $\mathrm{P} 2$ or P3. P1 and P3 are canonical TATA promoters and initiate transcription at exons $1 \mathrm{~A}$ and 2 respectively, while $\mathrm{P} 2$ is a high GC-content element that initiates transcription upstream of exon IC (Vasavada et al. 1993) (see Fig. 5). Alternative splicing occurs at the $5^{\prime}$ as well as the $3^{\prime}$ end of the gene, and PTHrP gene expression can be regulated both by level of transcription and by mRNA stability. The precise mechanisms that activate high levels of PTHrP gene expression in tumors that are associated with humoral hypercalcemia of malignancy have yet to be identified. 
In contrast to malignancy and embryonic tissue, evidence suggests that PTHrP mRNA and protein are minimally expressed in most adult tissues (Ikeda et al. 1989, Dunbar et al. 1998, 1999). The interfollicular epidermis has long been considered an example of a tissue which expresses high levels of PTHrP in adult animals (Merendino et al. 1986, Insogna et al. 1988). This stems from several lines of experimental evidence including the following: many immunohistochemistry studies that detected relatively intense immunoreactivity in a variety of epidermal layers (Danks et al. 1989, Hayman et al. 1989, Atillasoy et al. 1991, Rosol et al. 1993, Sharpe et al. 1998); tumor surveys that indicate keratinocyte-like squamous cell carcinomas are frequently associated with humoral hypercalcemia (Stewart et al. 1980); and reports that primary epidermal keratinocytes produce higher levels of PTHrP mRNA than other cultured cell lines (Thiede \& Rodan 1988, Ikeda et al. 1989, Vasavada et al. 1993). In contrast, in situ hybridization-based surveys of developing rodent skin failed to detect substantial PTHrP mRNA in the interfollicular epidermis; instead PTHrP transcripts appear to be expressed exclusively in hair follicles in both fetal and adult systems (Senior et al. 1991, Lee et al. 1995, Cho et al. 2003). The low levels of PTHrP mRNA expression observed in adult animals imply that transcription of the gene is tightly regulated (Dunbar et al. 1998, 1999, Cho et al. 2003).

Primary cultured keratinocytes grown in monolayers have provided a very useful model to probe the basic cell biology of the epidermis; however, this system provides an incomplete model. It lacks a basement membrane, dermal influences and interactions stemming from stratification. In addition, keratinocyte culture systems are designed to maximize proliferation, resulting in a large fraction of cells expressing markers of hyperproliferation usually associated with wound-healing or preneoplastic conditions (Jiang et al. 1993). A major characteristic of hyperproliferative keratinocytes is the production of a wide range of cytokines and growth factors, including those of the epidermal growth factor (EGF) family (Jiang et al. 1993, Pittelkow et al. 1993, Piepkorn et al. 1998). Primary human keratinocytes in vitro not only produce endogenous EGF-related growth factors (transforming growth factor (TGF)- $\alpha$, amphiregulin, and heparin binding (HB)-EGF), but also express their receptors (ErbB1, ErbB2 and ErbB3), establishing an autocrine loop of ErbB signaling (Piepkorn et al. 1998, Marques et al. 1999). Although EGF itself is not produced by keratinocytes, this factor is routinely added to defined media to facilitate adhesion and growth (Piepkorn et al. 1998). EGF or TGF- $\alpha$ have been reported to upregulate PTHrP gene expression in immortalized breast epithelial cells, lung and prostate carcinoma cells, as well as the immortalized human keratinocyte cell line, $\mathrm{HaCaT}$ (Burton \& Knight 1992, Ferrari et al. 1994, Heath et al. 1995, Cramer et al. 1996).
In this manuscript we investigate $\mathrm{PTHrP}$ mRNA expression in intact human skin taken from both neonates and adults, as well as cultured primary keratinocytes derived from these samples. Also, we present evidence that autocrine stimulation of the ErbB1 pathway is a major activator of PTHrP gene expression in keratinocytes in vitro. Finally, we identify the specific promoter, transcription factor binding site, class of transcription factor and second messenger signaling pathway that mediates ErbB1-induced activation of PTHrP gene expression.

\section{Materials and Methods}

\section{Reagents and cell culture}

EGF was purchased from Cascade Biologics (Portland, OR, USA), or supplied as one component of the human keratinocyte growth supplement (HKGS) kit. PD153035 (Calbiochem, San Diego, CA, USA) was dissolved in dimethyl sulfoxide (DMSO), stored at $-20{ }^{\circ} \mathrm{C}$ at stock concentration of $1.0 \mathrm{mM}$, and used at a final concentration of $1.0 \mu \mathrm{M}$. Human recombinant TGF- $\alpha(2.0 \mathrm{ng} / \mathrm{ml})$, amphiregulin $(1.5 \mu \mathrm{g} / \mathrm{ml})$, and HB-EGF $(8.0 \mathrm{ng} / \mathrm{ml})$ (all from Sigma, St Louis, MO, USA) were reconstituted in $0 \cdot 1 \% \mathrm{BSA}$ in PBS, these concentrations were respectively 5-, 30-, and 17-fold the $\mathrm{EC}_{50}$. Actinomycin D and CRM 197 (Sigma) were dissolved in DMSO or water, and used at $0 \cdot 1-10 \mu \mathrm{g} / \mathrm{ml}$. Anti-human goat amphiregulin antibody (R\&D Systems, Minneapolis, MN, USA) was reconstituted in PBS and used at $0 \cdot 1-5 \mu \mathrm{g} / \mathrm{ml}$. TGF- $\alpha$ monoclonal antibody (Ab-3) was obtained from Oncogene Research Products (San Diego, CA, USA), and was used at $0 \cdot 1-$ $5 \mu \mathrm{g} / \mathrm{ml}$. At these concentrations, all three neutralizing reagents were able to inhibit increases of PTHrP transcripts stimulated by the application of exogenous ligands to the culture (not shown).

\section{Skin samples and cell cultures}

The adult skin samples were obtained from reductive mammoplasty and neonatal skin samples were derived from circumcisions. Use of these materials has been approved by the Indiana University Purdue University Indianapolis Institutional Review Board (0010-30). The skin samples were briefly defatted, snap frozen in liquid nitrogen, and stored at $-80{ }^{\circ} \mathrm{C}$ until use. Primary normal human keratinocytes were isolated from breast skin and foreskin as previously described (Pentland \& Needleman 1986, Spandau 1994), and maintained in complete medium. The complete medium was composed of EpiLife basal medium supplemented with HKGS (Cascade Biologics) and $1000 \mathrm{U}$ penicillin-streptomycin (Roche). The components and their final concentrations of the supplements were $0 \cdot 2 \mathrm{ng} / \mathrm{ml}$ human EGF, $0 \cdot 2 \%$ bovine pituitary extract (BPE), $5 \mu \mathrm{g} / \mathrm{ml}$ bovine insulin, $0 \cdot 18 \mu \mathrm{g} /$ 
$\mathrm{ml}$ hydrocortisone, $5 \mu \mathrm{g} / \mathrm{ml}$ bovine transferin, and $0.06 \mathrm{mM}$ calcium chloride. All experiments were conducted while keratinocytes were proliferating and were no more than $70-80 \%$ confluent.

$R N A$ isolation and quantitative real-time reverse transcription PCR (Q-RT-PCR)

Total RNA was prepared using the RNeasy Mini kit (Qiagen, Valencia, CA, USA) according to the manufacturer's instructions.

Reverse transcription (RT) of total RNA was performed in a final volume of $50 \mu \mathrm{l}$. Total RNA $(1 \cdot 0 \mu \mathrm{g})$ was treated with RQ1 DNase (Promega Corp., Madison, WI, USA) in $1 \times$ PCR buffer, $5 \mathrm{mM} \mathrm{MgCl} 2,1 \mathrm{mM}$ dNTP, and $1 \mathrm{U}$ RNasin RNase inhibitor (Promega Corp.) at $37^{\circ} \mathrm{C}$ for $1 \mathrm{~h}$ prior to first strand cDNA synthesis. The DNase-treated total RNA was subjected to reverse transcription using $1 \mathrm{U}$ Moloney murine leukemia virus (MuLV) reverse transcriptase and $2 \mu \mathrm{M}$ random hexamers (Applied Biosystem, Foster City, CA, USA) at $42{ }^{\circ} \mathrm{C}$ for $30 \mathrm{~min}$. The reverse transcriptase was inactivated by heating at $75{ }^{\circ} \mathrm{C}$ for $5 \mathrm{~min}$ and cooling at $5{ }^{\circ} \mathrm{C}$ for $5 \mathrm{~min}$.

Quantitative real-time PCR (Q-PCR) was performed using QuantiTect SYBR Green PCR master mix (Qiagen) according to the manufacturer's instructions employing 5.0 $\mu \mathrm{l} \mathrm{cDNA}$. PCR reactions were performed in a DNA Engine Opticon System (MJ Research Inc., Waltham, MA, USA). The PCR cycling comprised an initial incubation at $95^{\circ} \mathrm{C}$ for $15 \mathrm{~min}$ to activate HotStarTaq DNA polymerase and 45 cycles of denaturation at $94{ }^{\circ} \mathrm{C}$ for $15 \mathrm{~s}$, annealing (temperature listed in Table 1 for specific transcripts) for $30 \mathrm{~s}$, and extension at $72{ }^{\circ} \mathrm{C}$ for 30 s. To verify the specificity of the PCR products, a melting curve analysis was routinely performed in the range of temperature from $55^{\circ} \mathrm{C}$ to $95^{\circ} \mathrm{C}$. No-template control and no RT-treated samples were included as negative controls; they did not produce significant signals.

\section{RNase protection}

RNase protection analysis of the promoter-specific transcripts was performed as previously described (Vasavada et al. 1993).

\section{Plasmids}

The human PTHrP-luciferase reporter gene constructs that were used have been described previously by Cataisson et al. (2003). The constructs bearing mutations on stat, ets-1, and smad-binding sites on the BglI-HindIII construct were generated by site-directed mutagenesis $(\mathrm{V}$ Richard and T J Rosol, unpublished data). The pCDNA3 -based expression vectors of ets- 1 , ets- 2 , and dominant negative ras and raf have been described previously (Quilliam et al. 1994, Brtva et al. 1995, Lindemann et al. 2001).

\section{Transient transfection}

Transient transfection was performed using FuGENE 6 reagent (Roche Applied Science) according to the manufacturer's instructions. Twenty-four hours after plating $7 \times 10^{4}$ cells in 12 -well culture dishes, keratinocytes were $20-30 \%$ confluent and were transfected with $0.5 \mu \mathrm{g}$ PTHrP reporter construct in $3 \mu \mathrm{l} \mathrm{FuGENE} \mathrm{6.} \mathrm{For} \mathrm{co-}$ transfection, $0.5 \mu \mathrm{g}$ PTHrP reporter construct and $0.25 \mu \mathrm{g}$ expression vector in $4.5 \mu \mathrm{l}$ FuGENE 6 were used. Each transfection mixture also contained $10 \mathrm{ng}$ cytomegalovirus (CMV)- $\beta$-galactosidase expression vector. After $48 \mathrm{~h}$ transfection, keratinocytes were washed twice in PBS and extracted with $200 \mu \mathrm{l}$ luciferase lysis buffer (Promega). Twenty microliters cell extract were used in a reaction mixture that contained beetle luciferin (Promega), and luciferase activity was measured in a TD-20/20 luminometer (Turner Designs, Sunnyvale, CA, USA). The luciferase activity was normalized to $\beta$-galactosidase activity with the exception of Ets cotransfection experiments or treatments with PD153035. Both of these conditions substantially repressed expression of the CMV driven- $\beta$ galactosidase vector; therefore, these transfections were normalized by measuring total protein in the extract. Total protein was measured with the BCA protein assay reagent kit (Pierce Biotechnology, Rockford, IL, USA).

\section{Statistical analysis}

Results are expressed as the mean \pm S.D. of triplicate determinations. Statistical comparisons are based on one-tail analysis of the Student's $t$-test, or a one-way ANOVA. A probability value of $<0.05$ was considered to be significant.

\section{Results}

PTHrP $m$ RNA expression is upregulated in keratinocytes in culture

In keratinocyte cultures, growth factor supplements facilitate proliferation and inhibit differentiation. To determine whether PTHrP expression in primary keratinocytes reflected that of the intact epidermis, PTHrP mRNA expression was evaluated in matched sets of intact neonatal foreskins and keratinocytes derived from those samples. The vast majority of mRNA from full thickness human skin samples appears to be derived from the epidermis (Urschitz et al. 2002). As shown in Fig. 1A, RNase protection detected PTHrP transcripts in RNA samples from primary neonatal keratinocytes, but failed to do so in samples from intact foreskin. 
Table 1 Conditions and standards used in the quantitative real-time reverse transcription PCR (Q-RT-PCR)

\section{Q-RT-PCR condition}

\begin{tabular}{llll}
\hline $\begin{array}{l}\text { Annealing } \\
\text { temperature }\end{array}$ & $\begin{array}{l}\text { Plate read } \\
\text { temperature }\end{array}$ & $\begin{array}{l}\text { Size } \\
(\mathrm{bp})\end{array}$ & Primer sequence \\
\hline
\end{tabular}

\section{Target cDNA}

GAPDH

PTHrP

Amphiregulin

HB-GF

TGF- $\alpha$ temperature

emperature

$60 \cdot 0^{\circ} \mathrm{C}$

$81 \cdot 0^{\circ} \mathrm{C}$

$57 \cdot 0{ }^{\circ} \mathrm{C}$

$72 \cdot 0{ }^{\circ} \mathrm{C}$

$60 \cdot 0{ }^{\circ} \mathrm{C}$

$74 \cdot 5{ }^{\circ} \mathrm{C}$

$60 \cdot 0^{\circ} \mathrm{C}$

$81 \cdot 0^{\circ} \mathrm{C}$

$60 \cdot 0^{\circ} \mathrm{C}$

$83 \cdot 0^{\circ} \mathrm{C}$ (bp)

232

(1)CCGCAC-3

R:5'-GGAAGAATCGTCGCCGTAAA-3'

93 F:5'-GCT TCA GCC GCC GCC TCA A-3'

R:5'-GGA AGA ATC GTC GCC GTA AA-3'

142

(5AAAGCTGGGAAGCAAA-3

R:5'-TGGAAAGAGGACCGACTCAT-3'

F:5'-GAAAGAAGAAAGGCAAGGGG-3'

F:5'-TAATGACTGCCCAGATTCCC-3

R.5'-GTGATGGCCTCCTTCTTCTG-3'
R:5'-CCCATGACACCTCTCTCCAT-3'

\section{Q-RT-PCR standards}

Size Concentration

(bp) Primer sequence

range

715 F:5'-CAT GGA GAA GGC TGG GGC TC-3' R:5'-GAT GGC ATG GAC TGGT GGT CA-3'

550 Human PTHrP cDNA

$1 \times 10^{9}-1 \times 10^{5}$ $1 \times 10^{8}-1 \times 10^{4}$ F:5'-TGA TCC TCA CAG CTG TTG CT-3' R:5'-TTT TTA CCT TCG TGC ACC TTT-3' F.5'-TTA TCC TCC AGG CCA CAA GC- ${ }^{\prime \prime}$ R:5'-CCC CTC TGC AGT CTG AAA TC-3' F:5'-CAG CAG TGG TGT CCC ATT T-3' R:5'-GAC CTG GCA GCA GTG TAT CA-3'

$F$, forward; $R$, reverse 


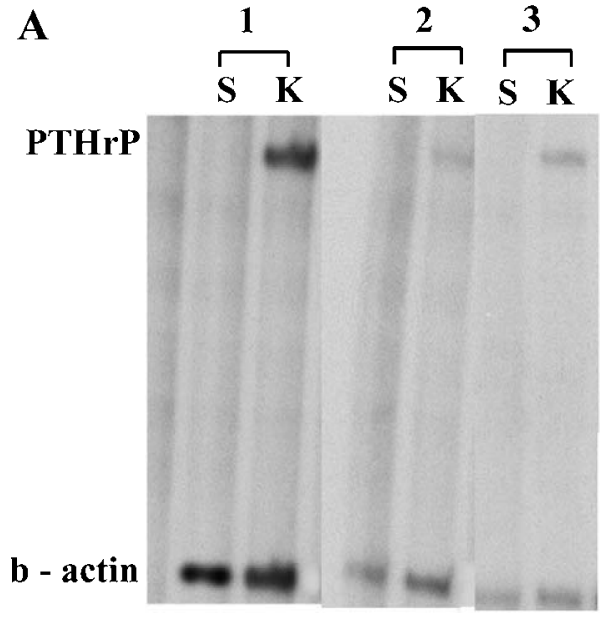

B

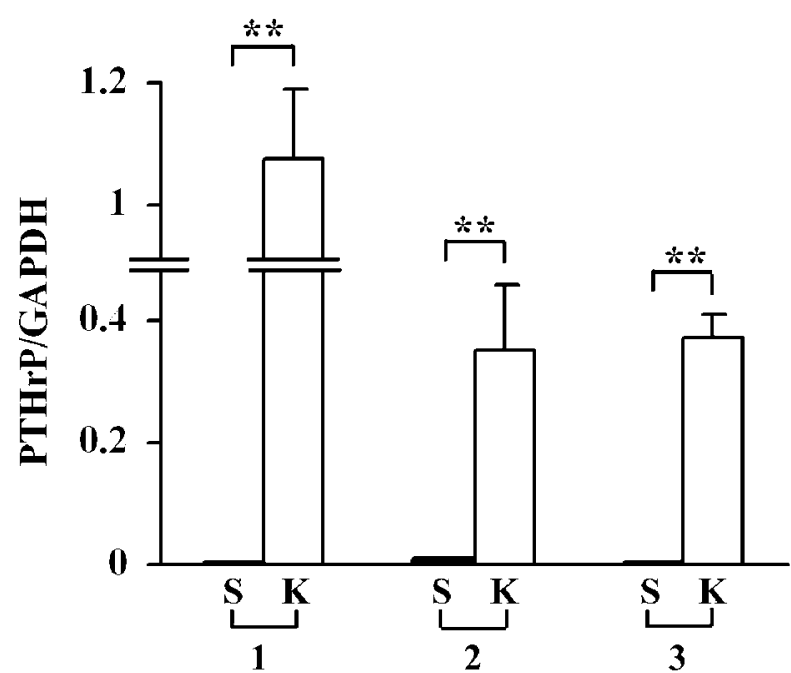

Figure 1 Cultured keratinocytes produce high levels of PTHrP mRNA relative to intact skin. (A) RNase protection was used to compare PTHrP mRNA levels in three matched sets of normal intact neonatal foreskin (S) samples and keratinocytes (K) derived from those samples. In the set on the left, the assay was performed using $30 \mu \mathrm{g}$ skin and keratinocyte RNA; for the remainder of the samples $10 \mu \mathrm{g}$ were employed. (B) Real-time quantitative RT-PCR was used to compare PTHrP mRNA levels in three matched sets of normal adult skin taken from the breast $(\mathrm{S})$ and keratinocytes $(\mathrm{K})$ derived from those samples. Values are the relative ratio of PTHrP mRNA to GAPDH mRNA and are expressed as means \pm S.D. of triplicate samples. ${ }^{*} P<0 \cdot 05 ;{ }^{* *} P<0 \cdot 01$.

The neonatal foreskin is distinct from the majority of human skin in that it has minimal appendages and contains an inner non-keratinized epithelium as well as the outer epidermis. We questioned whether the observation that keratinocytes contained much more PTHrP mRNA than intact skin could be generalized to adult skin of the trunk.

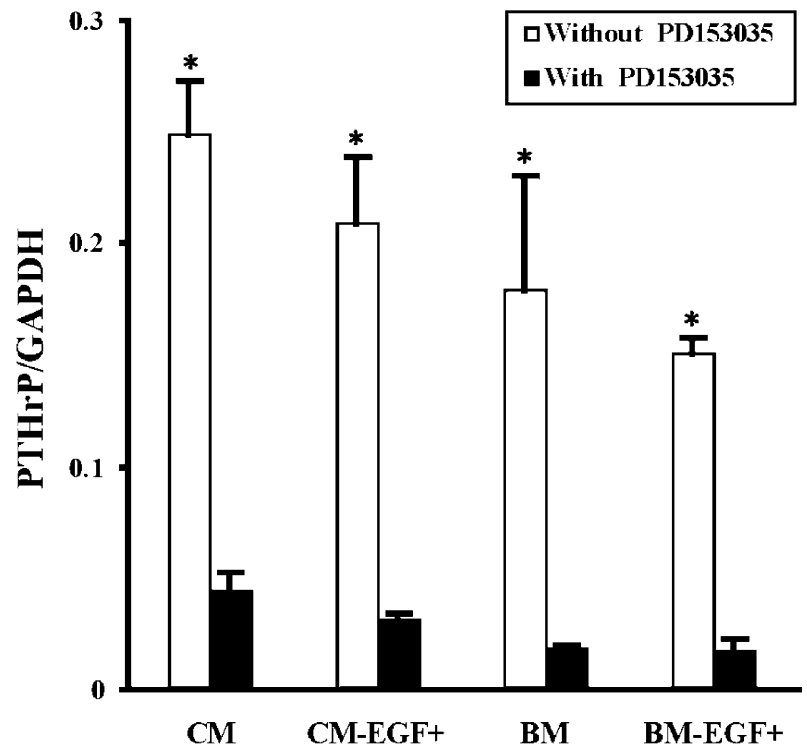

Figure 2 ErbB1 signaling activates PTHrP gene expression in keratinocytes. Keratinocytes were grown in complete medium $(\mathrm{CM})$ and in basal medium lacking all growth supplements (BM) $+/-E G F$, in the presence or absence of $1 \mu \mathrm{M}$ PD153035 for $3 \mathrm{~h}$. PTHrP and GAPDH mRNA levels were measured by Q-RT-PCR. Values are the relative ratio of PTHrP mRNA to GAPDH mRNA levels and are expressed as means \pm S.D. of triplicate cultures from a single experiment. These experiments were repeated three times using keratinocytes from different donors with similar results. ${ }^{*} P<0 \cdot 05$

To extend our findings, we purified RNA from matched sets of skins derived from breast reductions and keratinocytes grown from these samples. In this case, PTHrP mRNA levels were measured by real-time Q-RT-PCR. Like foreskin-derived keratinocytes, PTHrP mRNA levels were markedly higher in keratinocytes than in the intact skins (Fig. 1B).

\section{ErbB1 signaling is a major activator of $\mathrm{PTHrP}$ gene} expression in proliferating keratinocytes

It has been reported that EGF is a potent stimulator of PTHrP gene expression in many cell types (Ferrari et al. 1994, Heath et al. 1995, Cramer et al. 1996). Therefore, we reasoned that the presence of EGF as 'growth supplement' in keratinocyte media might activate PTHrP gene expression. To test this hypothesis, we measured PTHrP transcripts from RNA samples derived from rapidly proliferating keratinocyte cultures with and without EGF and those treated with the ErbB1 inhibitor, PD153035. The presence or absence of EGF had no impact on PTHrP mRNA levels in keratinocytes, whereas treatment with PD153035 markedly decreased transcripts by $82-85 \%$ as compared with non-treated samples (Fig. 2). We found that deprivation of bovine pituitary extract, insulin, hydrocortisone and transferrin did not substantially change the 
PTHrP mRNA levels (Fig. 2). These results suggest that ErbB1 receptor activity is a major stimulator of PTHrP gene expression in non-confluent keratinocyte cultures in the presence or absence of exogenous growth supplements, including EGF.
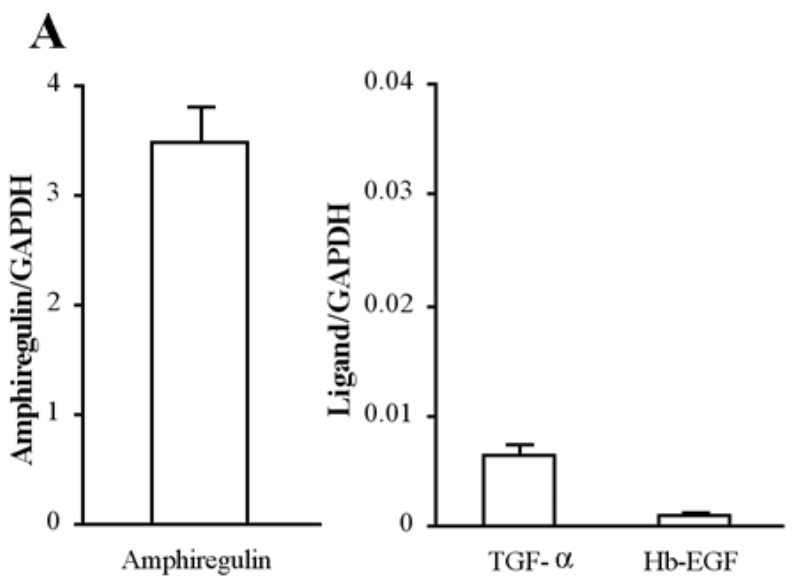

B

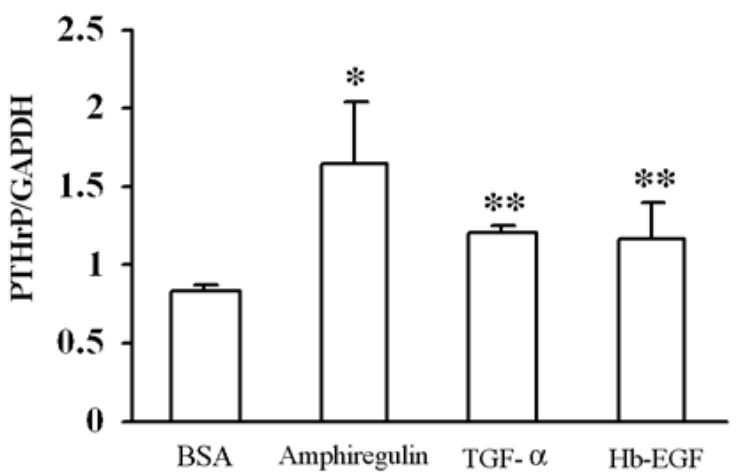

C

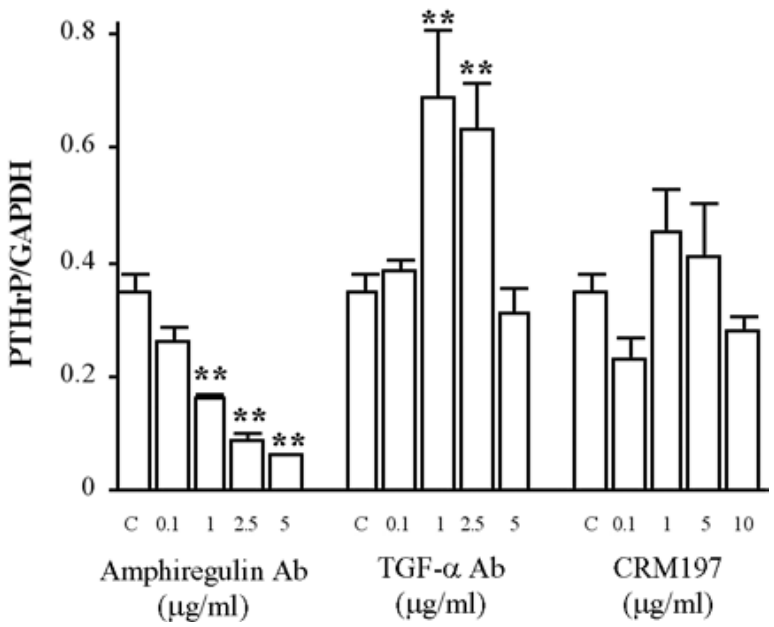

Endogenous amphiregulin stimulates PTHrP gene expression

In cultured keratinocytes, ErbB1 can be activated by endogenously produced EGF-like ligands (Pittelkow et al. 1993, Piepkorn et al. 1998). Initially, we evaluated amphiregulin, TGF- $\alpha$, and HB-EGF mRNA expression in our cultures of rapidly growing keratinocytes with Q-RTPCR. As shown in Fig. 3A, keratinocytes grown in this manner contained amphiregulin mRNA levels that were $>500$-fold greater than those of TGF- $\alpha$ and HB-EGF. Next, to determine if these factors stimulated PTHrP gene expression, we treated EGF-deprived proliferating keratinocytes with exogenous amphiregulin, TGF- $\alpha$ and HBEGF. As shown in Fig. 3B, they all slightly increased PTHrP mRNA levels (1.4- to 1.6-fold) compared with the non-treated control. To determine whether endogenous production of these factors activates $\mathrm{PTHrP}$ gene expression, we treated non-confluent keratinocytes with neutralizing reagents at various concentrations (antibodies to amphiregulin and TGF- $\alpha$ as well as CRM 197, a fragment of diphtheria toxin that binds HB-EGF and prevents it from stimulating ErbB1). Only the amphiregulin antibody produced a dose-dependent reduction in PTHrP mRNA expression (Fig. 3C). These findings suggest that autocrine stimulation of ErbB1 by amphiregulin accounts for the majority of PTHrP mRNA expression in cultured keratinocytes.

ErbB1 signaling activates PTHrP P3-TATA promoter, but does not increase $m R N A$ stability

We used actinomycin D treatment to investigate whether a blockade of ErbB1 signaling altered PTHrP transcript stability. We added $5 \mu \mathrm{g} / \mathrm{ml}$ actinomycin $\mathrm{D}$ to two groups of keratinocytes (one treated with PD153035 and one not treated) and observed PTHrP mRNA levels in samples from both groups at various times after treatment. As shown in Fig. 4, no difference in the stability of PTHrP mRNA was observed between the groups.

Figure 3 The stimulatory effect of endogenous EGF-like ligands on PTHrP gene expression in keratinocytes. (A) Relative amphiregulin, HB-EGF and TGF- $\alpha$ mRNA levels in proliferating keratinocyte cultures measured by Q-RT-PCR. The relative ratios of EGF-like ligand mRNA to GAPDH mRNA level were expressed as means \pm S.D. of triplicate cultures from a single experiment. Note that the $y$-axis of the right panel of $(A)$ is 100 -fold less than that of the left. (B) The effects of exogenous EGF-like ligands on PTHrP mRNA expression. The cells were treated with BSA or EGF-like ligands - amphiregulin, TGF- $\alpha$ and HB-EGF - for $3 \mathrm{~h}$ in media without EGF. (C) The effect of EGF-like ligand neutralizing reagents on PTHrP mRNA expression. Cells were treated with fresh media lacking EGF as control (c) or media with anti-amphiregulin antibody (amphiregulin Ab), anti-TGF- $\alpha$ antibody (TGF- $\alpha$ Ab), or HB-EGF blocking reagent CRM197 (CRM197) at the concentrations listed below the bars. Only the amphiregulin antibody produced a dose-dependent reduction in PTHrP mRNA. These experiments were repeated three times using keratinocytes from different donors with similar results. ${ }^{*} P<0 \cdot 05$; ${ }^{* *} P<0 \cdot 01$. 


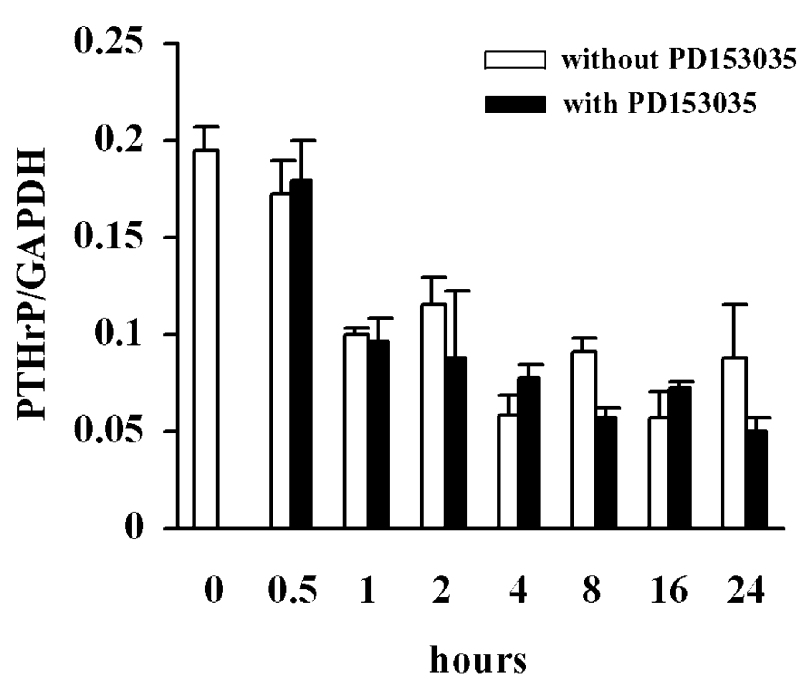

Figure 4 Blockade of ErbB1 signaling does not affect PTHrP mRNA stability. The cells were treated with $5 \mu \mathrm{g} / \mathrm{ml}$ actinomycin D with or without $1 \mu \mathrm{M}$ PD153035 added to the medium. Cells were harvested at the times indicated. Q-RT-PCR was used to measure PTHrP and GAPDH mRNA levels and the relative ratios of PTHrP to GAPDH mRNA level were expressed as means \pm S.D. of triplicate cultures. This analysis was repeated twice with keratinocytes from different donors with similar results.

To determine which of the three PTHrP promoters was activated by ErbB1 signaling, we performed a promoterspecific RNase protection assay on RNA from control keratinocytes and those treated with PD153035. In this assay we used a single probe that protected three distinct fragments, each derived from a different promoter (Fig. $5 \mathrm{~A})$. As shown in Fig. 5B, the majority of PTHrP transcripts were derived from the P3 promoter, and the level of transcripts was markedly decreased by PD153035.

To further define the $\mathrm{P} 3$ promoter region responding to ErbB1 signaling and establish that ErbB1 signaling regulated PTHrP gene expression at the transcriptional level, we used a transient transfection assay employing two P3 PTHrP reporter constructs cloned to the pGL2 basic luciferase vector. One was a $672 \mathrm{bp}$ BglI-HindIII $(-662 \sim+10)$ construct containing the upstream P3 promoter region. The other was a shorter deletion construct, $510 \mathrm{bp}$ AccI-HindIII $(-500 \sim+10)$ fragment, which contained only 15 bases upstream of the TATA box. As shown in Fig. 5C, the keratinocytes transfected with the $672 \mathrm{bp}$ PTHrP construct had 40 times the activity of the promoter-less pGL2 vector. The activity of this construct was repressed $80-90 \%$ by treating transfected cells with PD153035. Deletion of the region upstream of the P3 TATA box decreased the luciferase activity $\sim 95 \%$ and PD153035 treatment reduced the activity by about $10 \%$. This finding implies that cis-acting elements present in the -662 to -501 PTHrP P3 promoter region are required to activate $\mathrm{PTHrP}$ transcription in response to ErbB1 signaling.

The Ets binding site is required for high levels of P3 reporter gene activity

Within 60 bases upstream of the PTHrP P3-TATA box there is a cluster of functional binding sites for transcription factors such as STAT (signal transducer and activator of transcription), Sp-1, Ets and Smad binding (Dittmer et al. 1993, 1994, Lindemann et al. 2001). We used a transient transfection assay using the wild-type (672 base BglIHindIII) PTHrP P3 promoter and constructs with mutated binding sites for STAT (GAS), Ets-1 (EBS), and Smad (SBS) (Fig. 6A). The luciferase activity of reporter constructs with a mutated EBS was decreased by $55 \%$ as compared with the wild-type construct (Fig. 6B).

Ten ETS domain proteins have been detected in the epidermis and reports suggest that the expression level of these transcription factors was increased in cultured keratinocytes (Andreoli et al. 1997). Seven of the Ets factors in keratinocytes can bind to consensus motifs similar to the EBS site upstream of the PTHrP-P3 promoter (Sharrocks et al. 1997). To determine if Ets factors can directly influence PTHrP gene expression, we performed cotransfections with both the wild-type and EBS mutant P3 promoter constructs and Ets-1 or Ets- 2 expression vectors. As shown in Fig. 6C, Ets-1 and Ets-2 increased the wild-type P3 promoter reporter activity $>17$-fold but modestly activated the EBS mutant construct. This suggested that increased levels of Ets factors could activate the PTHrP-P3 promoter in keratinocytes.

ErbB1 signaling stimulates PTHrP gene expression through the ras/raf kinase pathway

Ets factors often mediate changes in gene expression triggered by the ras-MAP kinase (MAPK) pathway (Sharrocks et al. 1997, Jost et al. 2000). To determine if the ras-MAPK pathway mediates ErbBl activation of PTHrP gene expression, we performed a co-transfection assay employing the wild-type P3 promoter construct and expression vectors of dominant negative ras and raf. Expression of dominant negative ras and raf decreased the P3 promoter reporter gene activity by $\sim 70$ and $90 \%$ respectively (Fig. 7).

\section{Discussion}

The results presented here lead us to reconsider PTHrP expression in the epidermis. We found that the intact human epidermis from foreskins or trunk expresses very low levels of PTHrP mRNA that could not be discerned by RNase protection and were barely detectable by quantitative RT-PCR (Fig. 1). The initial surveys of 
$\mathbf{A}$

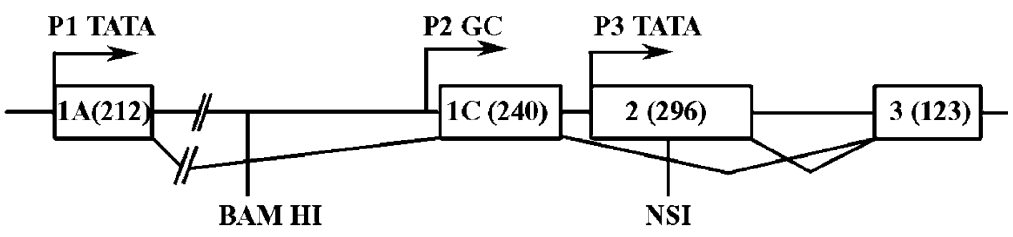

Probe

Protected fragments P2 GC

250 bases

P3 TATA

240 bases

160 bases

B
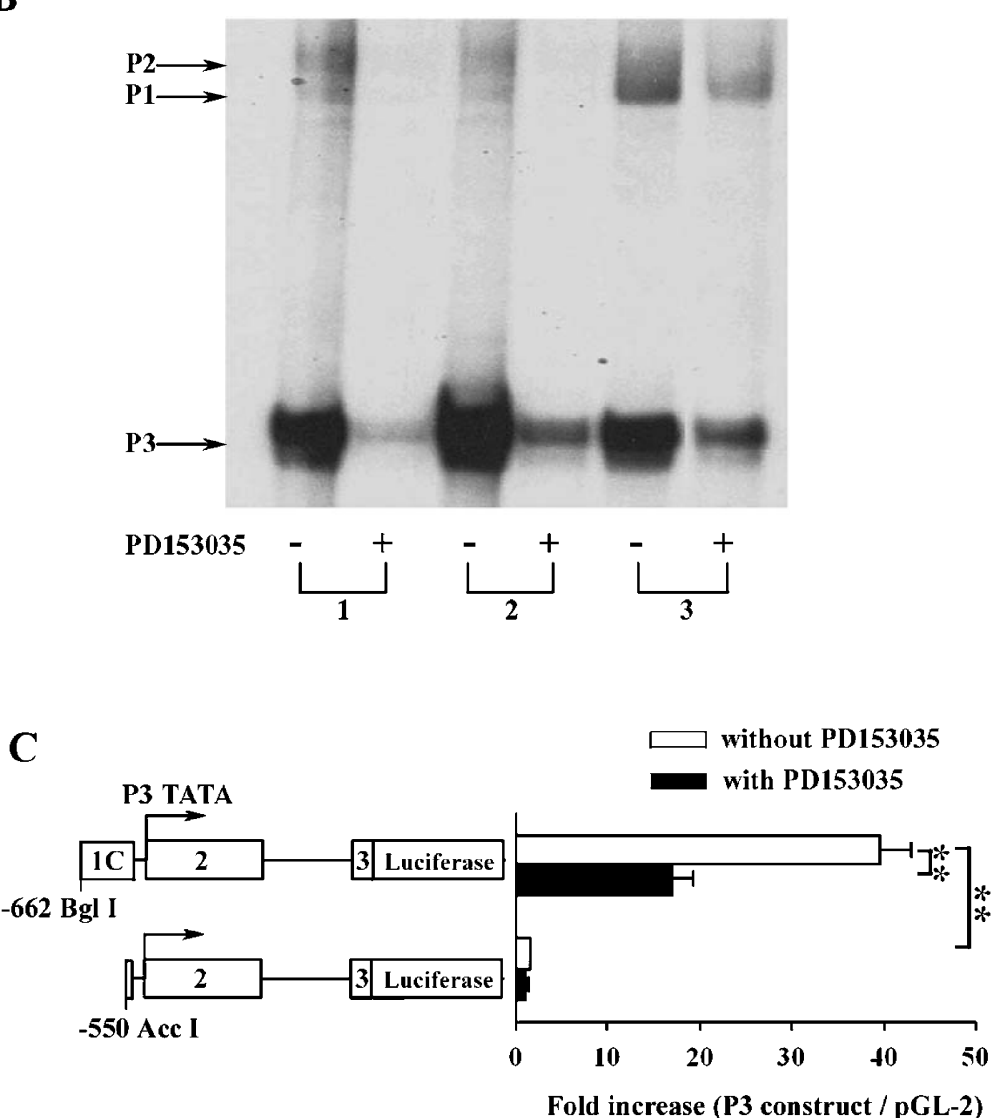

Figure 5 ErbB1 signaling activates transcription from the P3 promoter. (A) Schematic diagram of the human PTHrP gene; exons are shown as boxes, introns are lines. P1 TATA, P2 GC and P3 TATA promoters are shown as arrows and the alternative mRNA splicings are shown as solid lines below the gene. Sizes of the exons in bp are indicated in brackets within the exon boxes. The expected fragments generated from each of the three promoters in an RNase protection assay with the BAM-NSI probe are illustrated below the schematic. Transcripts produced from the P2 GC promoter initiate $10 \mathrm{bp}$ upstream of exon IC and therefore generate a 250-bp protected fragment. Transcripts produced from the P1 TATA include exon IC and therefore generate a 240-bp fragment. Transcripts produced from the P3 TATA initiated at exon 2 are the only transcripts that include this exon and generate a 160-bp fragment. (B) Each lane represents $40 \mu \mathrm{g}$ total RNA hybridized with the human BAM-NSI 5' probe. The intensity of the P3 promoter-derived transcripts was decreased in lanes treated with PD153035. (C) A transient transfection assay employing two PTHrP P3 promoter reporter constructs -662 Bgll $\sim+10$ HindIII and a shorter deletion construct $-500 \mathrm{Accl} \sim+10 \mathrm{HindIII}$, and a promoterless luciferase vector pGL-2. The constructs are numbered in reference to the ATG of the human PTHrP gene, denoted as +1 . Luciferase levels were normalized to total protein and plotted as fold activity of the pGL-2 vector expressed as means \pm S.D. of triplicate cultures. These experiments were repeated three times using keratinocytes from different donors with similar results. ${ }^{* *} P<0 \cdot 01$. 
PTHrP gene expression in primary human keratinocytes reported that the addition of EGF had a modest impact on secretion of immunoreactive PTHrP into the media (1.5to 2-fold) and stimulated short-term increases in PTHrP mRNA (Kremer et al. 1991). Consistent with these findings, we observed that the treatment of keratinocytes

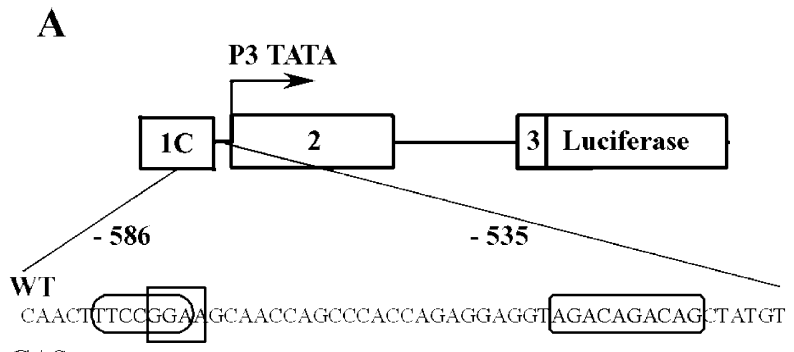

GASm

CAACT IagCGAAGCAACCAGCCACCAGAGGAGGTAGACAGACAGCTATGT

EBSm

CAACTTTCott A GAACCAGCCACCAGAGGAGGTAGACAGACAGCTATGT SBSm

CAACTTTCOGGAAGCAACCAGCCCACCAGAGGaGGTAGAt $\mathbf{t}_{\text {A }} \mathbf{t}_{\text {AG }}$ TATGT

B

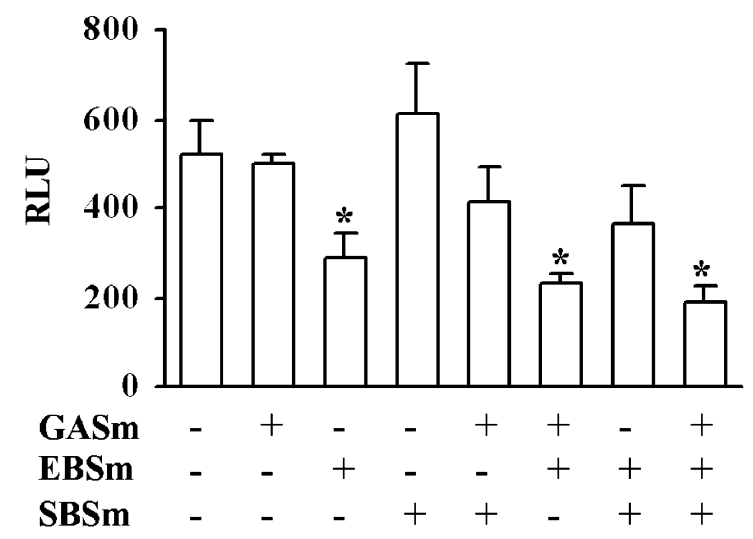

C

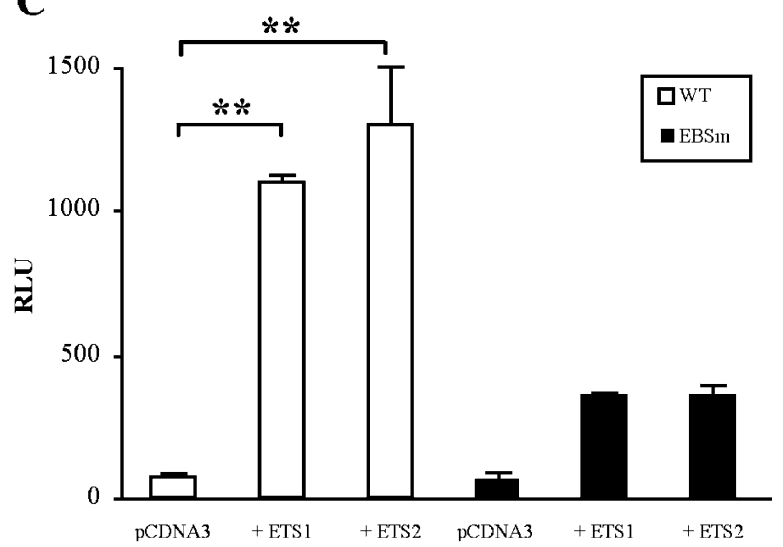

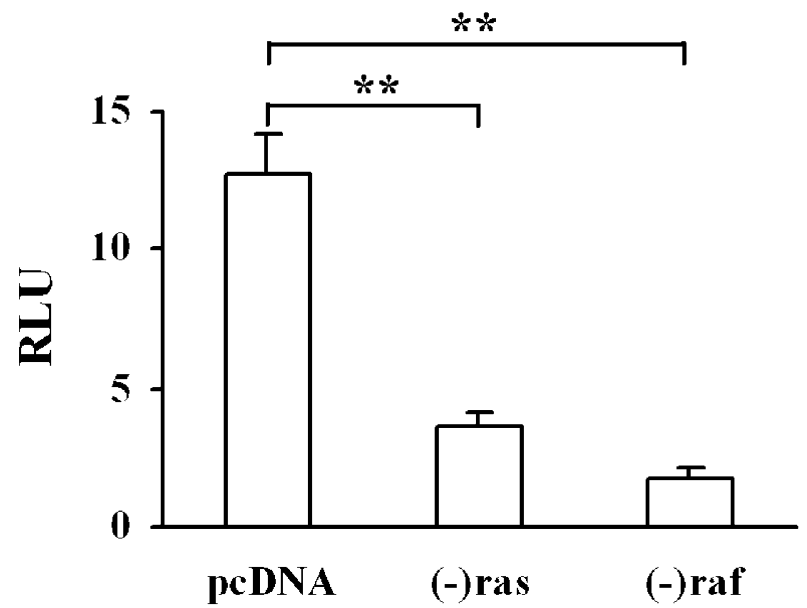

Figure 7 Blockade of ras and raf signaling inhibit PTHrP-P3 promoter reporter activity. Transient co-transfection assays employing PTHrP P3 promoter (construct and dominant negative ras or raf expression vector were performed as in Fig. 6) are shown. The luciferase activities were normalized to beta galactosidase levels, and all transfections were repeated at least three times with keratinocytes from different donors. The results of a representative experiment are shown. ${ }^{* *} P<0 \cdot 01$. RLU, relative luciferase units.

with HB-EGF, TGF- $\alpha$ and amphiregulin modestly increased PTHrP mRNA expression (1.4- 1.6-fold), whereas the low levels of supplemental EGF $(0.03 \mathrm{nM})$ had no impact on gene expression. We suggest that the production of EGF ligands, particularly amphiregulin, in cultured keratinocytes activates erbB1, resulting in relatively high levels of PTHrP gene expression. In contrast, the epidermis and dermis of intact skin produce low levels of these ligands (Cook et al. 1991, Piepkorn et al. 1998), and therefore would be expected to produce very little PTHrP. However, PTHrP gene expression would be predicted to be upregulated as a consequence of hyperproliferative epidermal conditions that are associated with

Figure 6 Ets binding site as a potential ErbB1-responsive element in the P3 PTHrP promoter region. (A) The sequences of the region between -586 and -535 of the wild-type (WT) -662 Bgl I

$\sim+10$ HindIII PTHrP P3 construct and its mutant constructs of STAT binding site (GASm), Ets binding site I (EBSm), and Smad binding site (SBSm). (B) Transient transfection assay comparing the reporter activity of the wild-type to that of its mutant constructs of individual or combinations of the mutations. (C) The wild-type P3 construct (open bars) or the EBSm construct (solid bars) cotransfected with Ets 1 and Ets2 expression vectors or the parental plasmid pCDNA3. Note cotransfection of the EBSm with pCNA partially obscured the effect of the mutation yet this construct was minimally activated by the addition of Ets factors. The luciferase activities were normalized to beta galactosidase levels in (B) and to protein levels in (C) and were expressed as means \pm S.D. of triplicate cultures. All transfections were repeated at least three times with keratinocytes from different donors and the results of a representative experiment are shown. ${ }^{*} P<0 \cdot 05$; ${ }^{*} P<0 \cdot 01$. RLU, relative luciferase units. 
high levels of EGF-like ligand expression. Consistent with this prediction, PTHrP transcripts were found to be increased in the migrating keratinocytes within wounds (Blomme et al. 1998).

Our measurements of PTHrP transcript levels in intact skin are at variance with the many immunohistochemical labeling studies which indicate that the cells of the epidermis contain substantial PTHrP immunoreactivity, consistent with a high rate of gene expression (Danks et al. 1989, Hayman et al. 1989, Atillasoy et al. 1991, Rosol et al. 1993, Sharpe et al. 1998). While the possibility exists that the intact epidermis stores PTHrP rather than constitutively secreting it (leading to substantial immunoreactivity), a more likely explanation for the immunohistochemistry findings is non-specificity of antibody reagents. We have used several N-terminal and midregion antibodies from commercial and private sources on skin from the PTHrP-knockout mouse under a wide variety of conditions and found that all labeled the epidermis (unpublished results). Thus, consistent with observations that most adult tissues express low levels of PTHrP, we suggest that the undisturbed epidermis produces very little of this protein.

The substantial reduction in PTHrP mRNA levels achieved by PD153035, as well as amphiregulin antibodies, suggests that PTHrP production in cultured keratinocytes is largely activated through autocrine stimulation of ErbB1 by amphiregulin. Consequently, additional exogenous EGF-like ligands would be expected to have a minimal impact on $\mathrm{PTHrP}$ gene expression in cultured keratinocytes. The immortalized keratinocyte cell line, $\mathrm{HaCaT}$, is often used as a model of keratinocytes; however, they produce exceedingly low levels of HB-EGF, TGF- $\alpha$ and amphiregulin when deprived of serum (Stoll \& Elder 1999). In contrast to primary keratinocytes, treatment of serum-deprived $\mathrm{HaCaT}$ cells with EGF resulted in a tenfold increase in immunoreactive PTHrP and a four- to eightfold increase in mRNA (Heath et al. 1995). Thus, the finding that the addition of exogenous EGF to $\mathrm{HaCaT}$ cells robustly activated the gene is consistent with our results.

Our findings suggest the following scenario for erbBmediated activation of PTHrP gene expression: EGF-like ligand binding leads to homodimerization of the ErbB1 receptor and activation of the ras-raf-MEK-ERK cascade, triggering Ets proteins to transactivate the PTHrP-P3 promoter. Stimulation of the ras-MAPK pathway appears to mediate activation of this calcitropic factor by a host of stimuli in many cell types (Aklilu et al. 2000, Kakonen et al. 2002, MacLeod et al. 2003). ErbB1 signaling has been reported to directly increase the expression of Ets factors in other cell types (Amorino et al. 2002), suggesting that PTHrP gene transcription may be activated, in part, by an increase in these transcription factors.

Although EGF-like ligands have been reported to activate PTHrP gene expression in a number of cell types, it has not been clear whether EGF-like ligands play a substantial role in the activation of PTHrP gene expression in primary keratinocytes. By using the specific ErbB1 tyrosine kinase inhibitor, PD153035, we found that activation of this pathway accounts for the majority of PTHrP transcripts expressed by keratinocytes grown in vitro. Autocrine activation of ErbB1 is a characteristic of a wide variety of tumors derived from epithelia (Yarden \& Sliwkowski 2001) and this pathway may account for increased PTHrP gene expression in many of these cell types.

\section{Acknowledgements}

The authors wish to thank Ron Osborne for assistance in editing the manuscript.

\section{Funding}

This work was supported by the National Institutes of Health grant AR45585 to J F and C A 779911 to T J R, the American Cancer Society Institutional Grant to Indiana University (IRG-84-002-15) and the Research Enhancement Program at the Indiana University School of Medicine. V R was supported by a Glen Barber fellowship from the Ohio State University.

\section{References}

Aklilu F, Gladu J, Goltzman D \& Rabbani SA 2000 Role of mitogen-activated protein kinases in the induction of parathyroid hormone-related peptide. Cancer Research 60 1753-1760.

Amorino GP, Hamilton VM, Valerie K, Dent P, Lammering G \& Schmidt-Ullrich RK 2002 Epidermal growth factor receptor dependence of radiation-induced transcription factor activation in human breast carcinoma cells. Molecular Biology of the Cell $\mathbf{1 3}$ 2233-2244.

Andreoli JM, Jang SI, Chung E, Coticchia CM, Steinert PM \& Markova NG 1997 The expression of a novel, epithelium-specific ets transcription factor is restricted to the most differentiated layers in the epidermis. Nucleic Acids Research 25 4287-4295.

Atillasoy EJ, Burtis WJ \& Milstone LM 1991 Immunohistochemical localization of parathyroid hormone-related protein (PTHRP) in normal human skin. Journal of Investigative Dermatology 96 277-280.

Blomme EA, Sugimoto Y, McCauley LK, Lin YC, Capen CC \& Rosol TJ 1998 Stromal and epithelial cells of the canine prostate express parathyroid hormone-related protein, but not the PTH/PTHrP receptor. Prostate 36 110-120.

Broadus AE, Mangin M, Ikeda K, Insogna KL, Weir EC, Burtis WJ \& Stewart AF 1988 Humoral hypercalcemia of cancer: identification of a novel parathyroid hormone-like peptide. New England Journal of Medicine 319 556-563.

Brtva TR, Drugan JK, Ghosh S, Terrell RS, Campbell-Burk S, Bell RM \& Der CJ 1995 Two distinct Raf domains mediate interaction with Ras. Journal of Biological Chemistry 270 9809-9812.

Burton PB \& Knight DE 1992 Parathyroid hormone-related peptide can regulate the growth of human lung cancer cells, and may form part of an autocrine TGF-alpha loop. FEBS Letters 305 228-232. 
Cataisson C, Gordon J, Roussiere M, Abdalkhani A, Lindemann R, Dittmer J, Foley J \& Bouizar Z 2003 Ets-1 activates parathyroid hormone-related protein gene expression in tumorigenic breast epithelial cells. Molecular and Cellular Endocrinology 204 155-168.

Cho YM, Woodard GL, Dunbar M, Gocken T, Jimenez JA \& Foley J 2003 Hair-cycle-dependent expression of parathyroid hormone-related protein and its type I receptor: evidence for regulation at the anagen to catagen transition. Journal of Investigative Dermatology $120715-727$.

Cook PW, Mattox PA, Keeble WW, Pittelkow MR, Plowman GD, Shoyab M, Adelman JP \& Shipley GD 1991 A heparin sulfate-regulated human keratinocyte autocrine factor is similar or identical to amphiregulin. Molecular and Cellular Biology 11 2547-2557.

Cramer SD, Peehl DM, Edgar MG, Wong ST, Deftos LJ \& Feldman D 1996 Parathyroid hormone-related protein (PTHrP) is an epidermal growth factor-regulated secretory product of human prostatic epithelial cells. Prostate 29 20-29.

Danks JA, Ebeling PR, Hayman J, Chou ST, Moseley JM, Dunlop J, Kemp BE \& Martin TJ 1989 Parathyroid hormone-related protein: immunohistochemical localization in cancers and in normal skin. Journal of Bone and Mineral Research 4 273-278.

Dittmer J, Gitlin SD, Reid RL \& Brady JN 1993 Transactivation of the P2 promoter of parathyroid hormone-related protein by human T-cell lymphotropic virus type I Tax1: evidence for the involvement of transcription factor Ets1. Journal of Virology 67 6087-6095

Dittmer J, Gegonne A, Gitlin SD, Ghysdael J \& Brady JN 1994 Regulation of parathyroid hormone-related protein (PTHrP) gene expression $\mathrm{Sp} 1$ binds through an inverted CACCC motif and regulates promoter activity in cooperation with Ets1. Journal of Biological Chemistry $26921428-21434$.

Dunbar ME, Young P, Zhang JP, McCaughern-Carucci J, Lanske B, Orloff JJ, Karaplis A, Cunha G \& Wysolmerski JJ 1998 Stromal cells are critical targets in the regulation of mammary ductal morphogenesis by parathyroid hormone-related protein. Developmental Biology 203 75-89.

Dunbar ME, Dann PR, Robinson GW, Hennighausen L, Zhang JP \& Wysolmerski JJ 1999 Parathyroid hormone-related protein signaling is necessary for sexual dimorphism during embryonic mammary development. Development 126 3485-3493.

Ferrari SL, Rizzoli R \& Bonjour JP 1994 Effects of epidermal growth factor on parathyroid hormone-related protein production by mammary epithelial cells. Journal of Bone and Mineral Research 9 639-644.

Gillespie MT \& Martin TJ 1994 The parathyroid hormone-related protein gene and its expression. Molecular and Cellular Endocrinology $100143-147$

Hayman JA, Danks JA, Ebeling PR, Moseley JM, Kemp BE \& Martin TJ 1989 Expression of parathyroid hormone-related protein in normal skin and in tumours of skin and skin appendages. Journal of Pathology 158 293-296.

Heath JK, Southby J, Fukumoto S, O'Keeffe LM, Martin TJ \& Gillespie MT 1995 Epidermal growth factor-stimulated parathyroid hormone-related protein expression involves increased gene transcription and mRNA stability. Biochemistry Journal 307 159-167.

Ikeda K, Arnold A, Mangin M, Kinder B, Vydelingum NA, Brennan MF \& Broadus AE 1989 Expression of transcripts encoding a parathyroid hormone-related peptide in abnormal human parathyroid tissues. Journal of Clinical Endocrinology and Metabolism 69 1240-1248.

Insogna KL, Stewart AF, Ikeda K, Centrella M \& Milstone LM 1988 Characterization of a parathyroid hormone-like peptide secreted by human keratinocytes. Annals of the New York Academy of Sciences 548 146-159.

Jiang CK, Magnaldo T, Ohtsuki M, Freedberg IM, Bernerd F \& Blumenberg M 1993 Epidermal growth factor and transforming growth factor alpha specifically induce the activation- and hyperproliferation-associated keratins 6 and 16. PNAS 90 6786-6790

Jost M, Kari C \& Rodeck U 2000 The EGF receptor - an essential regulator of multiple epidermal functions. European Journal of Dermatology 10 505-510.

Kakonen SM, Selander KS, Chirgwin JM, Yin JJ, Burns S, Rankin WA, Grubbs BG, Dallas M, Cui Y \& Guise TA 2002 Transforming growth factor-beta stimulates parathyroid hormone-related protein and osteolytic metastases via Smad and mitogen-activated protein kinase signaling pathways. Journal of Biological Chemistry 277 24571-24578.

Karaplis AC, Luz A, Glowacki J, Bronson RT, Tybulewicz VL, Kronenberg HM \& Mulligan RC 1994 Lethal skeletal dysplasia from targeted disruption of the parathyroid hormone-related peptide gene. Genes and Development 8 277-289.

Kremer R, Karaplis AC, Henderson J, Gulliver W, Banville D, Hendy GN \& Goltzman D 1991 Regulation of parathyroid hormone-like peptide in cultured normal human keratinocytes. Effect of growth factors and 1,25 dihydroxyvitamin D3 on gene expression and secretion. Journal of Clinical Investigation 87 884-893.

Lee K, Deeds JD \& Segre GV 1995 Expression of parathyroid hormone-related peptide and its receptor messenger ribonucleic acids during fetal development of rats. Endocrinology 136 453-463.

Lindemann RK, Ballschmieter P, Nordheim A \& Dittmer J 2001 Transforming growth factor beta regulates parathyroid hormone-related protein expression in MDA-MB-231 breast cancer cells through a novel Smad/Ets synergism. Journal of Biological Chemistry 276 46661-46670.

MacLeod RJ, Chattopadhyay N \& Brown EM 2003 PTHrP stimulated by the calcium-sensing receptor requires MAP kinase activation. American Journal of Physiology. Endocrinology and Metabolism 284 E435-E442.

Marques MM, Martinez N, Rodriguez-Garcia I \& Alonso A 1999 EGFR family-mediated signal transduction in the human keratinocyte cell line HaCaT. Experimental Cell Research 252 432-438.

Merendino JJ Jr, Insogna KL, Milstone LM, Broadus AE \& Stewart AF 1986 A parathyroid hormone-like protein from cultured human keratinocytes. Science 231 388-390.

Pentland AP \& Needleman P 1986 Modulation of keratinocyte proliferation in vitro by endogenous prostaglandin synthesis. Journal of Clinical Investigation 77 246-251.

Philbrick WM, Dreyer BE, Nakchbandi IA \& Karaplis AC 1998 Parathyroid hormone-related protein is required for tooth eruption. PNAS 95 11846-11851.

Piepkorn M, Pittelkow MR \& Cook PW 1998 Autocrine regulation of keratinocytes: the emerging role of heparin-binding, epidermal growth factor-related growth factors. Journal of Investigative Dermatology 111 715-721

Pittelkow MR, Cook PW, Shipley GD, Derynck R \& Coffey RJ Jr 1993 Autonomous growth of human keratinocytes requires epidermal growth factor receptor occupancy. Cell Growth and Differentiation 4 513-521.

Quilliam LA, Kato K, Rabun KM, Hisaka MM, Huff SY, Campbell-Burk S \& Der CJ 1994 Identification of residues critical for Ras $(17 \mathrm{~N})$ growth-inhibitory phenotype and for Ras interaction with guanine nucleotide exchange factors. Molecular and Cellular Biology 14 1113-1121.

Rosol TJ, Steinmeyer CL, McCauley LK, Merryman JI, Werkmeister JR, Grone A, Weckmann MT, Swayne DE \& Capen CC 1993 Studies on chicken polyclonal anti-peptide antibodies specific for parathyroid hormone-related protein (1-36). Veterinary Immunology and Immunopathology 35 321-337.

Senior PV, Heath DA \& Beck F 1991 Expression of parathyroid hormone-related protein $\mathrm{mRNA}$ in the rat before birth: demonstration by hybridization histochemistry. Journal of Molecular Endocrinology 6 281-290. 
Sharpe GR, Dillon JP, Durham B, Gallagher JA \& Fraser WD 1998 Human keratinocytes express transcripts for three isoforms of parathyroid hormone-related protein $(\mathrm{PTHrP})$, but not for the parathyroid hormone/PTHrP receptor: effects of $1,25(\mathrm{OH})_{2}$ vitamin D3. British Journal of Dermatology 138 944-951.

Sharrocks AD, Brown AL, Ling Y \& Yates PR 1997 The ETS-domain transcription factor family. International Journal of Biochemistry and Cell Biology 29 1371-1387.

Spandau DF 1994 Distinct conformations of p53 are observed at different stages of keratinocyte differentiation. Oncogene 9 1861-1868.

Stewart AF, Horst R, Deftos LJ, Cadman EC, Lang R \& Broadus AE 1980 Biochemical evaluation of patients with cancer-associated hypercalcemia: evidence for humoral and nonhumoral groups. New England Journal of Medicine 303 1377-1383.

Stoll SW \& Elder JT 1999 Differential regulation of EGF-like growth factor genes in human keratinocytes. Biochemical and Biophysical Research Communications 265 214-221.

Thiede MA \& Rodan GA 1988 Expression of a calcium-mobilizing parathyroid hormone-like peptide in lactating mammary tissue. Science 242 278-280.
Urschitz J, Iobst S, Urban Z, Granda C, Souza KA, Lupp C, Schilling K, Scott I, Csiszar K \& Boyd CD 2002 A serial analysis of gene expression in sun-damaged human skin. Journal of Investigative Dermatology 119 3-13.

Vasavada RC, Wysolmerski JJ, Broadus AE \& Philbrick WM 1993 Identification and characterization of a GC-rich promoter of the human parathyroid hormone-related peptide gene. Molecular Endocrinology 7 273-282.

Wysolmerski JJ, Philbrick WM, Dunbar ME, Lanske B, Kronenberg H \& Broadus AE 1998 Rescue of the parathyroid hormone-related protein knockout mouse demonstrates that parathyroid hormone-related protein is essential for mammary gland development. Development 125 1285-1294.

Yarden Y \& Sliwkowski MX 2001 Untangling the ErbB signalling network. Nature Reviews Molecular Cell Biology 2 127-137.

Received in final form 18 December 2003 Accepted 8 January 2004 